\title{
What Is and Where Is Francophone African Popular Fiction?
}

Pim Higginson

\begin{abstract}
Africa, and the specificities of its individual countries' colonial experiences, poses important questions concerning genre and popular culture. Specifically, it is difficult to situate something like, for example, "crime fiction," using the "culture industries" model proposed by Theodor Adorno and Max Horkheimer. Although helpful, Stuart Hall's major rehabilitation of the popular removed Adorno and Horkheimer's cultural elitism but nevertheless continued to tie the popular to a mode of production concomitant with late capitalism. What, this essay asks, should then be done with the "popular" productions of an African continent that has been systematically underdeveloped? Likewise, how should we categorize the work of Francophone African writers of noir whose books are principally sold in France? These cases further destabilize the already precarious concept of the popular, not only in its application to Africa, but globally.
\end{abstract}

Keywords: Francophone Africa, Anglophone Africa, cultural studies, genre, crime fiction, technology

The questions of my title are not as simple as they might appear. "What is Francophone African popular fiction?" asks for a set of criteria and definitions; "Where is it?" requests locations of production and readership. Both are at issue. What follows will be a manner of determining the concerns that arise when examining the "Francophone popular" and how these questions of definition challenge the idea of popular culture more generally as well as problematize the relations of cultural exchanges between the Global North and Africa. A series of crime novels written in French by African authors and published and distributed in France, and about which I have written extensively, serve as the starting point for this essay. The conundrum these works raise lies along two axes. The first concerns the viability of the concept of the "popular" as applied to African cultural products. The definitions of popular culture provided by such thinkers as Max Horkheimer and Theodor Adorno, or later, Stuart Hall, invite us to ask whether what takes place in the broadly defined African cultural sphere can be equated with their ideas of the culture industry and the popular-as-mass-culture it produces. The second axis concerns the specificity of the

Pim Higginson teaches at the University of New Mexico, in Albuquerque. His first book was The Noir Atlantic: Chester Himes and the Birth of the Francophone African Crime Novel (2011). Scoring Race: Jazz, Fiction, and Francophone Africa (Boydell and Brewer, 2017) examines jazz's reception in France and how that has impacted African authors. (Email: fhigginson@unm.edu) 
"Francophone," as opposed, most notably, to Anglophone Africa, with which it is most frequently compared. Defining this second question-that of Francophone popular culture's specificity-will, hopefully, underscore the importance of deciding the degree to which the idea of African popular culture in general, and Francophone popular culture specifically, makes sense while also drawing our attention to the parasitic relationship between what takes place in the Global North and in the Global South.

Before beginning, it is important to stress again that my argument emphasizes Francophone Africa, though it has implications for other parts of the continent and beyond. I am also not claiming that popular culture is absent in Africa if the term is applied to what, for example, Karin Barber and Stephanie Newell presented in their respective collections, Readings in African Popular Culture and Readings in African Popular Fiction. ${ }^{1}$ There exists a vast array of local and transnational forms of expression that merit recognition and analysis. Indeed, the question of how to define these local productions is not new. In his introduction to Popular Literatures in Africa, Bernth Lindfors had already recognized that:

[t]hose Africans who are literate tend to live and work in urban areas ... are an urbanized, acculturated elite, and their reading tastes tend to reflect their new interests and enthusiasms as well as their adjustment to conflicting sets of values and to modern city life. It is only among such people-a relatively small fraction of the population-that is possible to speak of the emergence of African popular literatures. $(1)^{2}$

Lindfors's questions about the popular here addresses principally the marketplace rather than the criteria by which the popular might be distinguished from "high" culture. At the same time, implicit in his thinking is that a limited readership (it is a "small fraction of the population") means a small number of potential consumers. Further, that these are "an urbanized and acculturated elite" caps the scale of production that might be achieved as it suggests that their tastes already tend toward Western products and less toward things locally produced-though the reality might be a more complicated mixed consumption. The volume of sales and the target audience suggest that conflating popular culture and mass culture will remain problematic. If, instead, we wish to continue to limit the popular to the conditions of the culture industry, as I propose to do, then the bulk-but not all-of the cultural production on the continent needs to be placed under a different label.

Karin Barber and Stephanie Newell likewise recognize the limited effectiveness of the idea of the popular if we continue to read it as synonymous with the product of the culture industry. Indeed, Barber very specifically addresses this inadequacy by problematizing the long-standing paradigmatic opposition between elite and traditional (or "folk") cultures. "What this paradigm has obscured," she argues, "is the cultural activities, procedures, and products of the majority of people in present-day Africa." Citing the example of Tanzanian detective novels and Cameroonian political

1 Karin Barber, ed., Readings in African Popular Culture (Bloomington, IN: Indiana University Press: 1997); Stephanie Newell, ed., Readings in African Popular Fiction (Bloomington, Indiana: Indiana University Press, 2002).

2 Berth Lindfors, Popular Literatures in Africa (Trenton, NJ: Africa World Press: 1991). 
cartoons (among others), Barber goes on to insist that "these genres are not repositories of some archaic 'authenticity.' " Rather, "they make use of all contemporary materials to speak of contemporary struggles." 3 At the same time, as Barber also recognizes, "when the term 'popular culture' is transferred to Africa it brings with it a history of conflicts, assumptions and problems." Barber and most of the writers that contribute to her volume use this term to describe the aesthetic forms of expression that emerge, most notably within urban spaces, however narrowly or broadly it might be defined.

Stephanie Newell, also posits several constraining conditions under which the essays she presents are gathered. The first, to which I will return, is that her volume has a very distinct "Anglophone orientation," which she adds "is intended to give readers a sense of the peculiar legacy of English literature to the post-colonial writer in Africa." 5 Newell likewise notes that "[b]ook production and consumption patterns in Africa differ greatly from those of late capitalist economies: the term 'popular,' " she notes, "therefore requires re-settling if it is to retain validity in modern African contexts." The extensive common ground here lies in the questions of modes of production and, to a large extent, the absence of mass production and therefore mass culture: both cases insist that like its Western counterpart, this is principally an "urban phenomenon,"7 while refusing to limit the term to mass culture.

What follows will revisit the question of the popular, not to deny the existence of what a multitude of researchers have identified as the vast and variegated field of cultural productions across urban socioscapes. Rather, it concerns what risks being elided in opening the "popular" back up from its mass-cultural moment. As Lindfors, Barber, and Newell all expressly assume, popular culture in the Global North and in Africa are two different things, and the sharing of a singular term for such potentially different phenomena may make it more difficult for us to see what prevents, for example, mass culture from happening in Africa. If the culture industry remains the basis for determining what is or is not popular culture, as has become increasingly the case in the West, it then becomes, as all three authors tacitly recognize, far more difficult to say that such a thing exists on the continent. Further, in the case of Newell, who admits the predominance of Anglophone references throughout her collection, it may be that unshackling the concept of the popular from its "Western" acceptation blurs or even elides the specificities of particular colonial legacies or national situations. Francophone Africa, the part of the continent that constitutes my own research bias, shares much in terms of colonial experience. But there is also much that is different. Most strikingly, there appears to be a programmatic stalling of industrialization that has marked France's colonial and neo-colonial relationship to the continent, a systematic anti-industrialization that is particularly noteworthy in the cultural sphere. This unabated meddling in the politics, and economies of its ex-colonies, has substantially limited local production of certain aesthetic forms, most notably perhaps, the writing on which Newell's collection concentrates and may have correspondingly imposed

3 Barber, Readings in African Popular Culture, 2.

4 Ibid., 2.

5 Ibid., 1.

6 Ibid., 4.

7 Ibid., 6. 
patterns of consumption that differ from other parts of the continent. Certainly, the vast array of popular writing available in the Anglophone African sphere and amply documented throughout Barber and Newell's texts is, if not entirely absent in the Francophone African world, at least severely stunted. This difference, I want to argue, is important for the specific context of Francophone Africa for reasons that I hope to make clear and may be important for understanding what is happening in Anglophone Africa as well. But to accomplish this analysis, I propose that it is necessary to resist prematurely opening the concept of popular culture to explain what is happening in most urban African contexts.

\section{What Is African Popular Culture?}

Whatever the context, discussions of culture are always fraught, and adding the dimension of the popular only exacerbates the range of critical tensions. One of the first mentions of "culture" as an object of study (at least in English) occurs in anthropologist Edward B. Tylor's Primitive Culture: Researches into the Development of Mythology, Philosophy, Religion, Language, Art and Custom (1871). There, premised on his notions of "permanence," "modification," and "survival," the author posits an evolutionary model that would proceed through a series of stages: savage, barbaric, and civilized. The Hegelian overtones of such a schema are hardly innocuous. In one sense Tylor provides a carefully circumscribed arena in which the emerging field of cultural anthropology will operate: culture is now the "complex whole which includes knowledge, belief, art, law, morals, custom, and other capabilities and habits acquired by man as a member of society." 8 At the same time, far more insidiously, Tylor's explicit reliance on an evolutionary model makes the entire enterprise fundamentally Eurocentric, not to say racist. That is, "fully formed" or "civilized" culture is viewed as exclusively European-all the rest, those "savage" and "barbaric" tribes-remain Hegelian stepping-stones on the way toward the fully constituted position from which the anthropological voice speaks. In this sense, as is immediately evident in the idea of "primitive culture," any qualification suggests not culture at all, but rather a protocultural phenomenon against which the West will measure the evolutionary distance it has traveled: its progress.

Dialectical thinking also guides the very different context of Theodor Adorno and Max Horkheimer's groundbreaking essay “The Culture Industry: Enlightenment as Mass Deception." 9 This famous Frankfurt School text posits, in an expression that for them is just as oxymoronic as Tylor's idea of "primitive culture," the notion of "mass culture." Here the concept of culture, emptied of its original and always already suspect (bourgeois) content, itself becomes synonymous with the moment of high capitalism and the alienation of the laborer in the emptiness of what the authors define as "leisure time." Adorno and Horkheimer see this convergence of art and the assembly line through the optic of a negative dialectic in which "culture" becomes

8 Edward B. Tylor, Primitive Culture: Researches into the Development of Mythology, Philosophy, Religion, Language, Art and Custom (London: John Murray, 1920), 1.

9 Theodor W. Adorno and Max Horkheimer, "The Culture Industry: Enlightenment as Mass Deception," Dialectic of Enlightenment: Philosophical Fragments, ed. Gunzelin Schmid Noerr, trans. Edmund Jephcott (Stanford, CA: Stanford University Press, 2002 [1944]), 94-136. 
synonymous with ever-decreasing ideological resistance to the "progressively" growing hegemony of capital," the "[t]echnical rationality" of which is "the rationality of domination." Technologically produced culture is, they tell us in no uncertain terms:

the compulsive character of a society alienated from itself. Automobiles, bombs, and films hold the totality together until their leveling element demonstrates its power against the very system of injustice it served. For the present the technology of the culture industry confines itself to standardization and mass production and sacrifices what once distinguished the logic of the work from that of society. ${ }^{10}$

In other words, culture under these conditions becomes a subset of the interests of capital, in which the world of "entertainment" seamlessly contributes to the interests of a system of global economic domination: "automobiles, bombs, and films" all emerge from the same factories and are motivated by the same forces. Culture, in this guise, becomes what the authors scathingly describe as "entertainment," where entertainment is merely a "prolongation of work" that is "sought by those who want to escape the mechanized labor process so that they can cope with it again," yet where "the off-duty worker can experience nothing but afterimages of the work process itself." ${ }^{\prime 1}$ This dystopia sees the worker and the machine merging into one soulless instrument whose purpose appears to be its own expansive and endless proliferation.

Without further glossing this oft-discussed text, it is nevertheless important to the present discussion that the authors' tacit understanding, following a Marxist dialectical-materialist model, is that culture itself (as the product of culture industry) operates either in the aesthetically rarefied world of the avant-garde (and the artistintellectual elite that regiment its terms of successful, that is resistant, production) or, in an advanced capitalist state: indeed, both are interdependent because avant-garde art is immediate and the only possible response to the alienation produced by and in mass culture. Given these significant assumptions about what popular culture is, what would be the status of popular culture in Africa, one of the exemplary locales of Tylor's "primitive culture"? There appears to be little room for "pre-" or "proto-" or even "para-"capitalist cultural production in "The Culture Industry" except in the nostalgia for "folk" forms that, the authors note, have been invented for or coopted by fascism. In short, if we maintain this idea of the culture industry-and doing so may be productive or even necessary-can African popular culture even exist? I struggled with this very dilemma when introducing my 2008 special issue of Research in African Literature, "Positively Popular: African Culture in the Mainstream."12

My introduction toyed with the ideas the present essay tries to better situate. Like Lindfors, Barber, and Newell before me, I struggled with the idea of "African popular culture." Indeed, the role of economic development in determining the field, and the ways in which colonial history more or less continues to overdetermine the cultural sphere in individual countries, may make the idea of the popular as it is commonly

10 Adorno and Horkheimer, "The Culture Industry," 95.

11 Ibid., 52, 109.

12 Pim Higginson, introduction to "Positively Popular: African Culture in the Mainstream," ed. Pim Higginson, special issue, Research in African Literatures 39.4 (Winter 2008): vii-x. 
used-that is, once again, as synonymous with "mass culture" in the Global Northdeeply problematic. The framing provided by Taylor on one hand and by Adorno and Horkheimer on the other indicates precisely why this might be the case. Despite my own hesitations, I followed in my predecessors' footsteps and accepted the idea of popular cultures while remaining aware of its limitations.

Indeed, there was, it appeared, a precedent and a further theoretical justification for this choice coming from the Birmingham School, most notably for me, Stuart Hall's famous "Notes on Deconstructing 'The Popular,' " which at least partially resolved this problem. ${ }^{13}$ Indeed, Hall's text opens space in the hardly concealed cultural elitism inherent to Adorno and Horkheimer's understanding of the proletariat as a passive consumer of the cultural industry's insipid products. Just as importantly, Hall's elaborate deconstruction, announced in the title of his essay, opens the possibility of a far more granular understanding of a broad spectrum of practices, spread out over time and spacepractices Adorno and Horkheimer refuse to recognize. Perhaps the most important feature of Hall's vital new definition is that contrary to the totalizing premise of the "culture industry" the popular becomes, among other things, the sedimented residue of repeated struggles for power: the product of a perpetual exchange between capital and the masses, and within each category-capital and masses-as well. At the same time, Hall's radical intervention and reinvention of the idea of popular culture(s) nevertheless continues to borrow heavily from a Marxist progressive model of history (albeit through a Gramscian lens) in which popular cultural forms remain interpellated by (late) capitalist modes of production-indeed, on the very British economic model to which Marx turned most frequently in formulating Capital.

Thus, despite the evident usefulness of Hall's argument, and those who have pursued his project such as Iain Chambers, Paul Gilroy, Hazel Carby, and many others, the idea of African popular culture remains vexed because the object itself is either contained within national parameters or is assumed to exist beyond those parameters without the question of the "popular" being systematically problematized. Indeed, my choice to apply an expanded idea of the popular in the wake of Lindfors, Barber, and Newell didn't dwell on the genealogy of the idea nor on the risks of doing so. Confronting Adorno and Horkheimer with Hall (and his legacy) leads to the conclusion that the culture industry is not a monolith; what consumers do with its industrial products is neither consistent nor singular. Rather, even within the constraints of the culture industry, an elaborate heterological exchange (of capital, of ideological interests, of local concerns, of creative impulses and recuperations) takes place between the means of production and the "masses." At the same time, as this also implies, the context to which Hall refers is of capital speaking not to just any people, but to its people (or masses) - in this case, the British proletariat, fluidly and broadly defined, and those people answering back.

In the context of Africa, something rather different appears to be happening. There is, with some important exceptions that I will address following, little mass cultural production in the African context, certainly within the Francophone African socioscape and, to a lesser extent, within Anglophone Africa (not including the unique

13 Stuart Hall, "Notes on Deconstructing 'The Popular,'" Cultural Theory and Popular Culture: A Reader, ed. John Story (New York: Prentice Hall, 1998), 442-53. 
case of South Africa). Instead, if we wish to examine the effects of popular culture (in the sense implicit in Adorno and Horkheimer's analysis) on the African continent's "masses," we would have to look at how Western products are consumed in that context. That is, what is the relationship between the industrial North's manufacture of cultural products and their consumption in the Global South, most notably, in Africa? What is clear when one transits through the continent's cities is that this is not a case, as described in "The Culture Industry," of mass production explicitly tailoring its objects of consumption for a specific ideological effect. Rather, as with so many other Western (and increasingly, Asian) industries, Africa is where capital takes out its trash: recycled clothes and cheap knock-offs, the worst of its pulp fiction, and most strikingly, perhaps, its failed films and television series. ${ }^{14}$

It is in this rather different context that the kind of improvisatory repurposing that Hall speaks of in "Notes on Deconstructing the 'Popular' " should be located. What we find is a dizzying proliferation of aesthetic enterprises that connect local performances with global networks of production. Yet, at the same time, it may be premature to ascribe to these the idea of popular culture precisely because they do not occur in the closed ideological feedback loop of production and consumption that the culture industry implies. These African art forms that, in many cases, are simultaneously creative products and equally creative consumptions were never part of the intentional closed circuit that holds popular culture together in the Global North. Rather, when viewed from the perspective of the West, these cultural practices (of building, playing, music, dance, painting, storytelling, punning, graffiti, etc.) achieve a kind of hallucinatory diversity, particularly when viewed from the disciplinary perspective of Western patterns of enjoyment.

In sum, that such repurposing is done, that the dregs of industrial culture are consumed and transformed and combined with local human and material resources is evident to anybody who travels throughout the continent and experiences how people dress, how and what they drive, and, from the Global North's perspective, the unexpected uses to which the West's (cultural) trash is put. But in this case, and in opposition to the "culture industry" model, there is no leisure time (which would require an industrialized economic order in which regular "shifts" could be counted upon) that marks that third part of the day when the worker is neither at the factory nor sleeping. Likewise, there is no immediate line of communication between industry - which is listening to an altogether different audience-and the accidental consumer for whom the product was never intended. As already suggested, the infinite feedback loop of capital that Adorno and Horkheimer imagine doesn't happen in this context. Rather, what would be an anarchic consumerism for the culture industry takes over. This consumption blends seamlessly with local forms of expression, modifying them just as they modify the object being consumed. These new and unexpected practices

14 Though the advent of satellite television has, to a degree changed things, it remains striking for any Western visitor to view films made, for example, in the United States that one has never heard of (let alone seen) with unknown (and laughably bad) actors playing in primetime on African screensthough it is worth noting that this very phenomenon existed in France as well, where badly dubbed thirdrate Hollywood productions slowly colonized French television, particularly the private channels. Indeed, these films (whether produced in the United States, Brazil, Saudi Arabia, India, or France) are clearly the dregs of a cultural industry whose interest lies elsewhere. 
generate their own codes and ethics, and in so doing create ever new patterns of use. In a sense, they are the expected result of what Achille Mbembe describes as "the [African] subject's deployment of a talent for play and a sense of fun which makes him homo ludens par excellence" precisely because that subject must occupy a multitude of different positions as a survival strategy in the face of the grotesque nature of post-colonial regimes of domination. ${ }^{15}$

Although I will return to this latter point in my conclusion, what becomes clear is that, to the extent that Africa is a collection of countries that have not entered late industrial capitalism (and perhaps may never be allowed to do so), neither the idea of the "culture industry" nor the concept of "popular culture" proposed by Hall is entirely adequate. Rather, if we accept the fact that the idea of the "popular" has forever been marked by its merging with "mass culture," the more apt expression for what has proliferated across the African continent might be instead be "vernacular culture," that is, cultural forms developed in the moment by and for local communities with varying degrees of commodification. Using this criterion, there are some (significant) emerging "popular" forms on the continent (particularly in music and video, which I will address later), but the bulk of what has been labeled "popular" remains in the realm of the vernacular precisely because it has not been (extensively) commodified. I am not, of course, inventing this label. In her 1960, essay, "Vernacular Culture," Margaret Lantis proposed the term to describe the accumulation of practices that could be classified as neither high nor low.

\begin{abstract}
Why not call it "vernacular culture"? The more accurate and complete term is "the vernacular aspect or portion of the total culture," but if the concept is acceptable, the short form probably will be used. It expresses "native to ..." or common of a locality, region, or, by ex- tension, of a trade or other group: the commonly used or spoken as distinct from the written" (Webster). The Latin does not seem to suggest traditional or primitive, but rather "of one's house," of the place. This is the connotation that we want: the culture-as-it-is-lived appropriate to well-defined places and situations. ${ }^{16}$
\end{abstract}

Although the term is not without its own limitations (it does not, for example, exclusively address aesthetic production), and there has been some resistance, as with the idea of "popular culture," for its potential devalorization in the face of "high" culture, it nevertheless resolves many of the issues I raised concerning the idea of the "popular." Most notably, in the African context it allows for some of the distinctions I wish to establish here. Additionally, even in this, one of the first references to the idea of vernacular culture, Lantis places it in an urban setting, precisely the one that interests me.

\title{
What of Francophone African Popular and Vernacular Cultures?
}

Having thus differentiated between vernacular and popular cultural forms, what follows will surface some of the questions raised earlier in the context of Francophone and Anglophone literary productions. I wish to ask whether either Francophone or

15 Achille Mbembe, "Provisional Notes on the Postcolony," Africa: Journal of the International African Institute 62.1 (1992): 3-37, esp. 5.

16 Margaret Lantis, “Vernacular Culture,” American Anthropologist 62.2 (April 1960): 202-16, esp. 203. 
Anglophone Africa can be said to produce a popular print fiction in some of the genres identified with the popular (e.g., mass-produced detective fiction, romance, self-help books, etc.) in the West. And to add a further complication, to what extent do the texts that circulate in France as popular African fiction count as popular (or vernacular) fiction in Africa? Stated differently, to what extent do these works feed (or emerge from) Western culture industry and to what extent do they bear the marks of located (vernacular or industrialized) places of production? Such questions become pressing in the Francophone context because of the centrality of its Metropole as the place within and from which its fiction gains legitimacy and currency.

The status of vernacular literature is, it would appear, very different in Francophone Africa and Anglophone Africa. As Barber and Newell's collections show, there has been substantial vernacular literature in Anglophone Africa. Conversely, in Francophone Africa, with a small number of exceptions, there has been very little literary production that resembles, for example, Onitsha market literature. ${ }^{17}$ The change of location, from one colonial history to another, becomes pressing when one attempts, as I did, to situate a body of Francophone African crime novels within the context of either "mass culture" or "vernacular culture." Indeed, where exactly should we situate the works of such authors as Bolya, Abasse N'Dione, Achille Ngoye, Mongo Beti, and Aïda Diallo? The Francophone African authors of crime fiction partake in a genre traditionally affiliated with the "popular" in the Global North and yet are published in some of France's most well-known specialized collections (such as Gallimard's Série noire). In addition, as with most of the "high" literary production in both Francophone and Anglophone Africa, they were principally read in France. In short, what might have been a Francophone African popular or vernacular literature is instead being transformed into a French commodity. In the meanwhile, in Francophone Africa, to the extent that people are buying books at all, it is for the most part the dross of the Western literary marketplace (the lowest of mass culture-crime, romance, etc.) with the occasional African author (usually canonical) sprinkled in. The latter bear stickers with the price doubled from the suggested retail price in France. It is no surprise then that such books (usually covered with a plastic sleeve to protect them over the long haul) rarely sell: being out of the price range of the average book buyer (an already limited market), they are principally for display.

All of this became apparent to me as I was working through the material that became The Noir Atlantic: Chester Himes and the Birth of the Francophone African Crime Novel. Although I emphasized that these authors inspired by Himes were preoccupied with the idea of the popular and how African authors negotiated the

17 My research in several West and Central African capitals (Dakar, Abidjan, Bamako, Libreville, Yaoundé) in 2003 led me to tentatively conclude that, in contrast to Anglophone countries such as Ghana, Nigeria, and Kenya, local literary productions were not readily available. Indeed, with the notable exception of an abundant production of musical CDs and DVDs, as far as public spaces such as marketplaces and bookstores where concerned, the Francophone capitals seemed devoid of material "vernacular literature" created on location. The one caveat to this conclusion would be that by 2003 the video revolution had already gained momentum and may have largely replaced print media in Anglophone countries as well. Nevertheless, interviews conducted in marketplaces and visits to every major bookstore suggested that there had never been much of a market for locally printed fiction in French in the first place. 
(potentially) negative connotations of such a term, ${ }^{18} \mathrm{I}$ more or less consciously operated under an ambiguity: the tacit understanding that Francophone African "detective" or noir fiction was a niche product dedicated to-and principally consumed in-the French marketplace while continuing to work with these texts as if they were part of African popular fiction. In a word, the authors I examined participated not in some putative African literary market so much as they served as representatives of the so-called Dark Continent within the French culture industry: ${ }^{19}$ they were part of French popular culture, albeit in a manner that I argued, coining the expression "the frivolous literary" for the purpose, ${ }^{20}$ involved a high degree of self-awareness on the part of these authors. To find locally produced and consumed French detective fiction, I had to turn to one of the earliest Francophone African authors, Togolese writer Felix Couchoro (1900-1968). ${ }^{21}$ Ironically, it appeared that Couchoro was a rare case of African vernacular fiction in French. ${ }^{22}$

This problem apparently presents itself rather differently in countries whose colonial legacy connects them to Great Britain. The contributors to Barber and Newell's collections identify in those countries a rich diversity of literary, artistic, and visual cultures. What both collections powerfully demonstrate is that Anglophone Africa's unique colonial and postcolonial histories have facilitated a thriving economy of textual and visual productions. As already suggested, the case of the texts produced in Onitsha, for example, remain essentially vernacular cultural forms. These are locally written, printed, and distributed. As Donatus Nwoga described it in his seminal "Onitsha Market Literature," 23 and Don Dodson further elaborated in "The Role of the Publisher in Onitsha Market Literature,"24 these texts principally consisted of pamphlets mimeographed or printed locally and sold door to door or in open air

18 Pim Higginson, The Noir Atlantic: Chester Himes and the Birth of the Francophone African Crime Novel (Liverpool: Liverpool University Press, 2011).

19 In this sense, and in varying ways, they partook of what Graham Huggan so brilliantly and provocatively identified as the "postcolonial exotic." Graham Huggan, The Postcolonial Exotic: Marketing the Margins (New York: Routledge, 2001).

20 It was my hope with this expression to insist on the unique position of African authors for whom the conditions of "seriousness" inherited from nineteenth-century notions of literature and from subsequent third-worldist conceptions of instrumentalized "revolutionary writing" had shaped the canon. The "frivolous," most notably through the turn to the popular genre of "noir," became a unique mode of resistance to the mechanisms that overdetermined Francophone African writing as "engaged."

21 For more on Couchoro see Pim Higginson, "Popular Perceptions: Voice and Genre in Felix Couchoro's Crime Fiction," Journal of Postcolonial Writing 49.1 (2013): 87-99.

22 In Writing and Popular Culture in Cameroon, Richard Bjornson makes a compelling case for the appearance of popular fiction in Cameroon (Umeå, Sweden: University of Umeå Press, 1990). Unfortunately, the books that form his canon, such as Omo Ya Eku's La prison sous le slip d'Ebela [The Prison Under Ebela's Underwear], were published by La Pensée Universelle, a Paris house specializing in low budget editions that were published for and immediately shipped to the Cameroonian marketplace, further complicating an already complicated picture. For another discussion of a similarly complicated popular form see, Lydie Moudileno, "The Troubling Popularity of West African Romance Novels," Research in African Literatures 39.4 (Winter 2008): 120-32.

Adoras is published by the heavily subsidized and largely French owned (Hachette) and controlled Nouvelles Éditions Ivoiriennes in Abidjan, Côte d'Ivoire.

23 Donatus Nwoga, "Onitsha Market Literature," Readings in African Popular Fiction, ed. Stephanie Newell (Booomington, IN: Indiana University Press, 2002 [1965]): 37-44.

24 Don Dodson, "The Role of the Publisher in Onitsha Market Literature," Readings in African Popular Fiction, ed. Stephanie Newell (Booomington, IN: Indiana University Press, 2002 [1973]): 44-51. 
markets, frequently by their authors. Generally, they contained plots and characters whose principle narrative motivation was pedagogical. They resulted, in short, from loosely collected series of individual enterprises where the product generated income and was destined for the moral and social improvement of the purchaser. Though the market has radically changed since Onitsha's heyday in the 1960s, there remains to this day in the Anglophone world a substantial locally produced popular or "genre" fiction that serves an African readership. ${ }^{25}$

The same is more difficult to argue for Francophone Africa. Whether we are speaking about manuals, textbooks, or fiction ("genre" or otherwise), most materials read in Francophone Africa are printed or published in France-more specifically, in Paris. The postcolonial African nation and the old colonial power therefore remain sutured not only through a vast network of economic ties, not the least of which is the continued use of the Franc CFA ${ }^{26}$ but also through an intellectual domination in which "speaking" in printed form usually happens through the adjudicating mechanism of the French/Parisian publishing monopoly. Francophone African fiction as it circulates in France is, as was the case of the crime novels on which I have worked, a kind of "provincial" subcategory of French fiction. National and local presses do exist and have historically existed in Francophone Africa, among the most famous being the now defunct Nouvelles Éditions Africaines (today NEAS and NEI). Editions Clé would be another notable one. These, however, remain tied to the "métropole" through subsidies and other forms of French editorial control, as is evident in the substantial ownership interest of Parisian publishing houses Hachette, Armand Colin, Nathan, and Éditions du Seuil in otherwise ostensibly African operations. The importance of Dakar and Abidjan, capitals of two countries closely allied to France historically (most notably through presidents Léopold Sédar Senghor and Félix Houphouet-Boigny) also tells us something about the limited degree of independence such publishing ventures might have.

Confirming my point, when asked by Nicolas Michel during an interview for the French magazine Jeune Afrique, "Considérez-vous que la littérature africaine francophone se développe toujours quasi exclusivement à Paris?" ${ }^{27}$ Franco-Congolesecritic Boniface Mongo-Mboussa put it succinctly:

Oui. Et c'est vrai pour la culture en général! Le dire soulève un tollé, mais Paris est la capitale littéraire africaine, même si des auteurs comme Felwine Sarr et Boubacar Boris Diop essaient de changer les choses, au Sénégal notamment. Où est-ce que Senghor, Césaire et Damas ont créé la négritude? Où se trouve la maison d'édition Présence africaine ${ }^{28}$

25 For an immediate sense of the market that remains for traditionally published books in Anglophone Africa and the types of works that are being distributed, see Emma Shercliff, "Books for the Masses? Publishing Genre Fiction in Africa: Africa Writes, 13 July 2014," Africa in Words (blog). August 18, 2014, https://africainwords. com/2014/08/18/books-for-the-masses-publishing-genre-fiction-in-africa-africa-writes-13-july-2014/.

26 A regional currency directly pegged to the Euro and the French economy.

27 "Do you believe that Francophone African literature is still produced more or less exclusively in Paris?" See "Boniface Mongo-Mboussa: 'La littérature africaine a perdu de son pouvoir de subversion,' " interview by Nicolas Michel, Jeune Afrique, October 29, 2014, http://www.jeuneafrique.com/41314/ culture/boniface-mongo-mboussa-la-litt-rature-africaine-a-perdu-de-son-pouvoir-de-subversion/.

28 "Yes. It's true for culture in general! Saying this will raise howls of protest, but Paris is the literary capital of [Francophone] Africa, even if authors such as Felwine Sarr and Boubacar Boris Diop are trying 
Neither today nor in the past (suggested by the reference to "négritude") has Francophone African literary culture succeeded in disengaging itself from diverse forms of French domination that continue to manifest themselves through, among other things, the literary marketplace. To summarize, whether one accepts the apparent boosterism of Paris as the literary capital of Francophone Africa implicit in Mongo-Mboussa's claim, or whether one finds it deeply problematic, it remains true that, to the extent that it can be said to exist at all, "popular fiction" in Francophone Africa remains highly dependent on-if not entirely defined by-French economic control. This will pertain so long as the neo-colonial cooptation of Francophone African cultural production as a subset of the continuing broader exploitation of its ex-colonies-what Xavier-François Verschave called "Françafrique"-continues. ${ }^{29}$ In addition, because what France produces that is "African" is far too expensive for the average African consumer, very little if anything produced in France can be consumed in its ostensible place of composition. Thus, with very few exceptions, the production by Francophone writers (and filmmakers) that are said to represent Africa is significantly geared toward French consumers.

\section{Revisiting the Culture Industry}

Returning to my earlier invocation of Adorno and Horkheimer, if we are to stick to a "cultural industry," late-capitalist context of production, it should be clear that, even in Anglophone Africa, it may still be problematic to speak of "popular" forms of culture. That is, using the notion of mass production as a guideline, to what extent can Onitsha market literature and its descendants be considered "popular" culture rather than "vernacular" culture? Although deciding this would demand identifying some imaginary threshold of commodification at which point a form goes from vernacular to popular, recognizing the possible differences between these two modes of production/consumption provides an important instrument for explaining what is happening in given contexts. For example, in specific parts of Anglophone Africa, vastly more sophisticated means of production and distribution are emerging in the literary sphere and, even more strikingly and convincingly, in the widely discussed video industries that have developed in countries such as Nigeria, Kenya, and Ghana. ${ }^{30}$ Indeed, although it is not my intention to dwell on visual culture, it is worth recalling how dominant Nigeria has become in the productions of videos now consumed throughout the African continent and even globally. Nollywood cinema, as it is often called, is one of the top two or three largest video sources in the world (some even claim it is the largest). To this we can add River Road, or Riverwood (as it is also known), productions in Kenya. Ghana likewise has a growing video industry that is taking advantage of new digital technologies and the ever-lower costs of production

to change things, most notably in Senegal. Where did [Léopold Sédar] Senghor, [Aimé] Césaire and Léon-Gautran Damas create négritude? Where is the Présence Africaine publishing house?" Ibid.

29 François-Xavier Verschave La Françafrique, le plus long scandale de la République (Paris: Stock, 2003).

30 South Africa clearly represents an important exception to much of what I am discussing here. Although it merits a substantial discussion, given its own vexed industrial development, I cannot go into it further here. 
and distribution. This, then, is a rare and striking case not of vernacular culture, but of a full-fledged popular cultural form being created and marketed from an African industrial center.

Here, finally, we see an industry that has gained a critical economic mass (where it is disseminated far beyond its local context of production) that directly feeds the consumption patterns and fantasies of its public. That is, Nigerian video constitutes an industry because it is consumed throughout Africa and the diaspora. In this sense, the evolving magnitude of Nollywood underscores the degree to which analysis of popular culture on the African continent needs to be more finely tuned to recognize the complex relationship between popular and vernacular forms. Indeed, even in the case of Nollywood, the concept of a "culture industry" cathected-as Adorno and Horkheimer would have it-to the overall mission of nationally defined instruments of capital (cars, bombs) may have to be amended because the cultural references (codes of dress, uses of vernacular languages, etc.) are, initially, local and the relationship between industry and state remain far less evident-though this also speaks to an increasingly global economy that remains one of the significant weaknesses of Adorno and Horkheimer's model.

Much of the need for refining the terminology is that Africa has, as Walter Rodney long ago argued, been systematically and deliberately underdeveloped. For that reason, it does not have the industrial infrastructure that readily allows for popular aesthetic production subservient to the larger instruments of nationally defined capital. ${ }^{31}$ Any analysis of African popular culture as popular (i.e., mass) needs to be done within a global schema, rather than a national one. At this point, the question would be: To what extent does Nollywood, for example, serve the purpose of global capital? To what extent does it speak to a local proletariat and its "leisure" time? To the degree that something like a culture industry and its attendant popular culture has awoken in Anglophone Africa, it seems fair to ask what its relation to global capital might be and to whose proletariat it speaks. It is within these parameters that I reassess Francophone African "popular culture" as well.

Stated differently, the Francophone case suggests that we redefine how we understand the idea of the African popular more generally. In Francophone African noir, on the one hand, we indeed have a "popular" genre as it is published by massdistribution publishers in France. At the same time, this production is outside of its ostensible place of production and is destined for Western-not African-consumers. On the other hand, we have African people creating their own variegated vernacular forms, much of this, with the West's cultural refuse. Finally, and it is with this that I wish to conclude, there is a connection between these two movements: they appear to mimic broader economic patterns in which raw goods from Africa are transformed by Western industry and then subsequently sold back to the African consumer as transformed industrial products. This pattern is indeed an important guide. Nevertheless, what is different in the production and circulation of culture is the unpredictable ways that the African consumer treats the objects of Western industrial production, transforming them into vernacular forms often disconnected from their intended use in the Global North.

31 Walter Rodney, How Europe Underdeveloped Africa (London: Bogle-L'Ouverture Publications, 1973). 
The Western culture industry pays little attention to the African market as it creates its products. Rather, it floods it with its trash: the unsold, the unsuccessful, the patently bad or useless. Yet despite this disregard for the last consumer, this transformation of sub-Saharan Africa into a landfill of mass production, the improvisatory consumption occurring within this vast and diverse market produces its own unanticipated aesthetic and social forms. These forms, precisely because they are detached from the perpetual feedback loop between industry and consumer, in turn serve as a creative resource for the West. The culture industry is therefore always doubly, parasitically dependent on the global south in general and on Africa in particular: as a continental rubbish bin for every imaginable form of material waste. The culture industry has an insatiable appetite for an energy that hasn't been dulled by relentless repetition. As Adorno and Horkheimer remind us, for the cultural industry to work, there needs to be:

\begin{abstract}
incessant talk of ideas, novelty and surprises, of what is both totally familiar and has never existed before. Tempo and dynamism are paramount. Nothing is allowed to stay as it was, everything must be endlessly in motion. For only the universal victory of the rhythm of mechanical production and reproduction promises that nothing will change, that nothing unsuitable will emerge. ${ }^{32}$
\end{abstract}

This need for change means that that the basic resources of culture, just like the basic resources of industry, need to be endlessly available. In the case of Africa, circumstance, distance, and patterns of exploitation have made "African vernacular culture" a powerful raw resource the Global North can exploit without ever recognizing its embedded specificity.

African music has perhaps been most radically exploited in this manner, and this process has been amply discussed, ${ }^{33}$ but so have novels, films, the arts, and fashion. Indeed, it was my argument in The Noir Atlantic that a distinct group of authors were, in different ways and to varying degrees, complicit in their own self-exoticization while also recognizing its inevitability within the global literary industry. Each recognized the degree to which, in France, the category littérature africaine had become a marginalized subgroup of the novel within the book market. With few exceptions, the readership for Francophone African "literature" is limited to a few academics and a minority of the public seeking the exotic. Although none of these authors' "crime" novels became best-sellers, their presence in such collections as the famous Série noire assured them sales to a faithful fan base willing to buy any crime fiction appearing with the immediately recognizable black-and-white cover. Further, in the process, these authors negotiated a complex path through a Western episteme that reduces African writing to an oxymoron. Indeed, one (more) reason that African popular culture is a problematic notion is that culture itself, as the product of a

32 Adorno and Horkheimer, "The Culture Industry," 106-07.

33 See for example, the classical case of Paul Simon's Graceland album discussed in Louise Meintjes, "Paul Simon's Graceland, South African, and the Mediation of Musical Meaning," Ethnomusicology 3.1 (1990): 37-73.

Although the essay emphasizes the spirit of cooperation involved in a number of places, it also underscores the degree of exploitation involved. 
bourgeois tradition leading to consumer capitalism, has been denied the African continent. Under such conditions, these writers chose to control the terms of their own exploitation to the greatest extent possible and to underscore in the process the very precariousness of African writing.

In conclusion, the task I have assigned myself throughout this essay has been to identify the difficulty of applying some key terms of cultural studies to the postcolonial Francophone African context. Further, I hope to have shown that this context demonstrates the infinitely diverse ways in which nationally bounded cultural domains cross-pollinate while also too often, but not always, mirroring the imbalance of power between global north and global south. At the same time, underlying ebbs and flows, and the unique way in which the West's trash is repurposed in Africa, also confuse the economic and historical geographies of the global north and global south in ways that remain to be further analyzed. I hope to have demonstrated that differentiating between postcolonial economic and linguistic zones needs to be part of this analysis. Likewise, new instruments need to be invented that will successfully capture the multiple gradations that lead from local vernacular aesthetic expressions to the scope and scale of the culture industry that dominates patterns of consumption in the Global North. These new parameters, whichever they are, will have to appreciate the multiply refracted creation, circulation, and exploitation that constitutes African cultural production in the past, today, and into the foreseeable future. 